УДК 2 - 1;2;2 - 3;224.5

\title{
АНАЛИТИЧЕСКИЙ ОБЗОР ОСНОВНЫХ ИССЛЕДОВАНИЙ КНИГИ ПРОРОКА ДАНИИЛА В НАУЧНЫХ ТРУДАХ УЧЁНЫХ ДУХОВНЫХ ШКОЛ ХІХ И ХХ ВЕКОВ
}

\author{
Плохий Евгений Викторович \\ слушатель \\ Религиозная организация - духовная образовательная \\ организация высшего образования \\ Белгородская Православная Духовная \\ семинария (с миссионерской направленностью) \\ Православной религиозной организации \\ Белгородской и Старооскольской епархии \\ Русской Православной Церкви Московского Патриархата \\ город Белгород, Российская Федерация
}

Аннотация: Автором представленной научной монографии осуществлена систематизация и аналитический обзор основных научных исследований и трудов, посвящённых историческому изучению и богословскому анализу Книги святого пророка Даниила в произведениях учёных Духовных школ XIX и XX веков.

Ключевые слова: Философия, православное богословие, библеистика, Священное Писание, Книга пророка Даниила, пророчество, научные труды учёных Духовных школ XIX и XX веков.

\section{ANALYTICAL REVIEW OF THE MAIN STUDIES OF THE BOOK OF THE PROPHET DANIEL IN THE SCIENTIFIC WORKS OF SCHOLARS OF THE SPIRITUAL SCHOOLS OF THE XIX AND XX CENTURIES}

Plokhii Yevgenii Viktorovich

Abstract: The author of the presented scientific monograph has carried out a systematization and analytical review of the main scientific studies and works devoted to the historical study and theological analysis of the Book of the Holy 


\section{ИННОВАЦИОННОЕ РАЗВИТИЕ НАУКИ: ФУНДАМЕНТАЛЬНЫЕ И ПРИКЛАДНЫЕ ПРОБЛЕМЫ}

Prophet Daniel in the works of scientists of the Theological schools of the XIX and XX centuries.

Key words: Philosophy, Orthodox theology, biblical studies, Holy Scripture, the Book of the Prophet Daniel, prophecy, scientific works of scholars of the Theological Schools of the XIX and XX centuries.

В рамках изучения текстов Священного Писания и Священного Предания [1] существует немало исследований, посвящённых рассмотрению различных аспектов Книги святого пророка Даниила. Однако необходимо отметить тот факт, что Книга святого пророка Даниила - как обширнейшая и многогранная тема исследования, остаётся всё ещё недостаточно разработанной. Сама по себе «Книга пророка Даниила занимает важное место среди канонических пророческих книг Ветхого Завета» [2, с. 243].

Внимательно проанализировав уже существующие научные исследования, относящиеся к изучению Книги святого пророка Даниила, мы выявили довольно существенный пласт научных трудов, осуществлённых в дореволюционный период и изложенных в научных трудах учёных Православных Духовных Школ XIX и XX веков в Российской Империи. Большая часть этих серьёзных и систематических научных трудов представляют собой докторские, кандидатские и магистерские диссертационные исследования, защищённые в период XIX и XX веков в Православных Духовных Академиях Российской Империи. По нашему мнению, эти разносторонние научные исследования не утратили своей научной ценности и важны для дальнейшего развития научного поиска. Однако, поскольку большинство этих научных трудов более ста лет не переиздавались, и являются малоизвестными и малодоступными для современных исследователей, то мы считаем, несомненно актуальным, рассказать об этих интересных научных работах. В связи с этим, предпринятый в нашей научно - исследовательской работе аналитический обзор основных научных исследований, посвящённых изучению Книги святого пророка Даниила в научных трудах учёных Духовных школ XIX и XX веков, может стать достойным вкладом в развитие изучения Священного Писания и Священного Предания.

В представленной монографии нами осуществлён систематический и аналитический обзор основных научных трудов преподавателей и 
профессоров Православных Духовных Школ, посвящённых изучению Книги святого пророка Даниила, которые были опубликованы в XIX и XX веках. Актуальность нашей научно - исследовательской работы состоит, прежде всего, в том, что она делает общедоступной информацию об этих научных трудах. Итак, в дореволюционный период изучению Книги пророка Даниила, исследованию её подлинности, переводу Книги пророка Даниила на русский язык, личности пророка Даниила, в том числе, и через православнобогословское понимание пророческих книг, а также исследованию святоотеческой экзегетической литературы о мессианских и эсхатологических пророчествах святого пророка Даниила, свои научные труды посвятили следующие учёные.

Павел Александрович Юнгеров (1856 - 1921 (1922)) - родился в Самарской губернии, сын священника, впоследствии прославленного в лике местночтимых святых - праведный Александр Юнгеров, Чагринский, протоиерей (1821 - 1910). (Дни памяти: 22 июня - Обретение мощей; 12 августа - Собор Самарских святых) [3]. Павел Александрович Юнгеров профессор Казанской Духовной Академии, переводчик Ветхого Завета на русский язык. Павел Александрович защитил диссертацию на тему «История и значение пророческого служения в иудейском народе». В своей научной работе П. А. Юнгеров основывается на текстах Септуагинты. Также в своих научных исследованиях он обращается к Масоретскому тексту и церковнославянскому переводу. В 1912 году П. А. Юнгеров излагает свой опыт перевода на русский язык Книги пророка Даниила с греческого текста. Существенное отличие перевода книги пророка Даниила, осуществлённого Павлом Александровичем Юнгеровым, заключается в том, что в его основе, как и славянского и общеупотребительного в православно-восточной Церкви библейского текста, лежит греческий перевод Феодотиона, а не «семидесяти толковников». Продолжая святоотеческие традиции в области библейской экзегетики и герменевтики, П. А. Юнгеров опирается на опыт отцов Древней Церкви. Например, священномученик Ипполит Римский, богослов и экзегет III века, писавший на греческом языке, основывал своё толкование Книги святого пророка Даниила на переводе Феодотиона [4]. Также и святитель Епифаний Кипрский [5], рассуждая о семидесяти толковниках, и о тех, кто ложно истолковывает Священное Писание, утверждает, что переводы Священного Писания Феодотионом Понтийским осуществлены, основываясь 
на еврейском подлиннике, прежде всего, для исправления перевода «семидесяти» [6]. Таким образом, П. А. Юнгеров внёс огромный вклад в уточнение переводов текстов Библии, а деятельность Павла Александровича Юнгерова по переводу Священного Писания была названа профессором Николаем Никаноровичем Глубоковским «великим научно-церковным подвигом» [7].

Сергей Александрович Песоикий (1869 - 1920) - писатель, преподаватель Киевской Духовной Академии, доцент по кафедре введения в круг богословских наук. В 1897 году он опубликовал научный труд, в котором рассмотрел исторический контекст служения святого пророка Даниила. Кроме того, Сергей Александрович Песоцкий исследовал культурологический аспект религиозности вавилонского общества, поскольку «деятельность пророка Даниила, проходившая на глазах всего высшего общества вавилонского, должна была оказывать могучее действие на склад религиозно - нравственных понятий вавилонян» [8, с. 491]. Также С. А. Песоцкий описывает динамику изменения мировоззрения еврейского общества эпохи пленения, в котором «одушевлённые речи и живая вера пророков в единого Бога - Иегову не остались бесплодными для народа: чудеса этого Бога, явленные и над язычниками, сильно действовали на ум и сердце каждого члена богоизбранного народа» [9, с. 488]. Таким образом, в своём научном исследовании С. А. Песоцкий доказал, что святой пророк Даниил - это человек, реально живший в эпоху вавилонского плена, и написавший в этом вавилонском плену свою богодухновенную книгу пророчеств.

Иван Фёдорович Григорьев (5. 10. 1873 - 1921) - профессор Казанской духовной академии. В 1918 году произнёс речь «в Торжественном годичном собрании Казанской духовной академии», представив «Критический этюд», в котором проанализировал русский синодальный перевод Книги пророка Даниила [10].

Алексей Федорович Разумовский (сведений о дате рождения и смерти не сохранилось) - преподаватель Витебской Духовной Семинарии. В 1891 году публикует в Санкт-Петербурге свой научный труд, посвящённый экзегетическому анализу Книги пророка Даниила. В этом научном исследовании А. Ф. Разумовский последовательно осуществляет детальный разбор содержания каждой главы Книги пророка Даниила. В частности, рассуждая о месте, которое Книга пророка Даниила занимает в еврейском 
каноне, он делает вывод о том, что «Книга пророка Даниила в еврейском каноне помещается в 3-ем отделе священных книг кетубим или агиографов, а не в числе книг пророческих - Невиим, как в тексте «семидесяти» и в Вульгате, и помещается между книгами Есфирь и Ездры» [11, с.14 - 15]. В том числе, особое внимание Алексей Федорович уделяет описанию и объяснению общекультурного контекста жизни иудеев в эпоху вавилонского пленения. Опираясь на исторические сведения из книг Иосифа Флавия, А. Ф. Разумовский размышляет о личности и жизни пророка Даниила, а также времени его пророческого служения. Не остались без внимания и чёткого изложения вопросы о цели написания, подлинности, принадлежности и языке написания Книги пророка Даниила. Излагая общий смысл этой ветхозаветной Книги, Алексей Федорович акцентирует внимание на исследовании вопроса о месте самого пророка Даниила в ряду других священных лиц ветхозаветной теократии, а также исследует и другие важные вопросы. Таким образом, несмотря на то, что информации об авторе этого научного исследования крайне мало, однако, содержание его книги до сих пор не утратило научной актуальности и значимости.

Иоанн Ксенофонтович (Смирнов), архиепископ Рязанский и Зарайский (24 августа 1844 - 14 октября 1919). В 1879 году в Губернской типографии города Рязани было опубликовано его научное исследование, которое посвящено толкованию на Книгу пророка Даниила [12].

Александр Матвеевич Бухарев (в монашестве архимандрит Феодор) (02. 08. 1822 (1824) - 14. 04. 1871) - духовный писатель, обучался в Тверской Духовной Семинарии и Московской Духовной Академии. В 1864 году А. М. Бухарев опубликовал в Москве свой научный труд, в котором тщательно изучает жизнь и пророческое служение святого пророка Даниила в рамках его исторической эпохи. В этом научном исследовании, в частности, анализируя смысл пророческого служения, Александр Матвеевич пишет: «Раскрыв пророческое поприще, предлежащие Даниилу соответственно его личным особенностям и обстоятельствам, удобно можем рассматривать содержание его книги». [13, с. 18 - 19]. Исходя из этого утверждения, А. М. Бухарев для лучшего понимания Книги пророка Даниила, полагает необходимым «разложить и разделить содержание Данииловой книги таким образом. Сначала рассмотрим изображённые в книге дела и откровения Божии, имевшие отношения не только к Израилю, но и к самим язычникам. Потом, 


\section{ИННОВАЦИОННОЕ РАЗВИТИЕ НАУКИ: ФУНДАМЕНТАЛЬНЫЕ И ПРИКЛАДНЫЕ ПРОБЛЕМЫ}

вникнем в смысл откровений, данных собственно по обстоятельствам и затруднениям избранного народа, - причём увидим и указания в книге, на отношение мира духовного к земнородным, и некоторое предначатие воззрений на предметы, предъявляющих в себе уже духовную отчётливость Ново - Заветной веры» [14, с. 19]. Особенно ярко в научном исследовании А. М. Бухарева изложен очень важный аспект - проповедь пророка Даниила среди язычников. Тем самым Александр Матвеевич указывает на то, что «основная мысль и цель этих Божественных дел и откровений, есть, соответственно требованию времени, проявление и пред языками всесодержащей державы истинного Бога и грядущего царства благодати» [15, c. 20]. Вместе с тем, А. М. Бухарев указывает на чёткие границы этой миссионерской деятельности пророка Даниила среди язычников. Александр Матвеевич отмечает, что пророчеств и откровений было дано язычникам ровно столько, сколько они могли вместить, то есть «Божественная истина просветила, насколько то было можно, неведение языков» [16, с. 93]. То есть, по мнению А. М. Бухарева, результатом пророческого служения святого пророка Даниила стало не только исправление нравов его собственного еврейского народа, но также духовное просвещение всех халдеев - язычников, живших в Вавилоне. Размышляя об этом явлении, А. М. Бухарев пишет, что «Господь не без плода давал откровения и чудодействовал среди языков; нашлись благосознательные, которые унаследовали себе, сколько можно, сокровище веры. .... Дух язычества сильно ещё преобладал над человеком, что сами собой опутывались сетью его и такие души, в которых уже были положены начатки веры» [17, с. 92]. Таким образом, совершенно понятным становится миссионерское значение проповеди святого Даниила, которое выражалось в том, что «Божественная истина просветила, насколько то было можно, неведение языков, поставила их дивными способами на свою стезю, противящихся победоносно низложила и благосознательными всемирно исповедана. Следовательно, она обозначилась между языками со всех существенных своих сторон. ... Так были удовлетворяемы, при служении или созерцании Пророка Даниила, великие духовные потребности языческого мира» [18, с. $93-94]$.

Также Александр Матвеевич Бухарев в 1864 году в Москве публикует научный труд, в котором исследует вопрос о подлинности Книги пророка Даниила, а также излагает существенные доказательства «происхождения 
Книги от святого пророка Даниила». В этом научном исследовании, А. М. Бухарев, резюмируя возражения, современным ему, западным библеистам, ставившим под сомнение авторство пророка Даниила его книге, Александр Матвеевич пишет: «Такое богатство сведений о порядке вещей в Халдейском и отчасти в Мидо - Персидском царстве, не встречающееся ни у единого писателя древности, есть поразительнейшее доказательство происхождения книги нашей не только не в Маккавейские времена, но и в век Даниила - ни от кого другого, кроме лица, знающего с точностью организацию правительства и в особенности касты мудрецов, - каков именно Даниил» [19, с. 110]. Таким образом, по нашему мнению, можно утверждать, что научные труды Александра Матвеевича Бухарева являются систематическим и достаточно полным исследованием Книги пророка Даниила актуальным и для современного православного богословия.

Александр Александрович Некрасов (1839 - 1905) - филолог, профессор Казанской Духовной Академии по кафедре греческого языка и его словесности. В 1887 году опубликовал аналитическую рецензию на статью господина Степана Дорошкевича, помещённую в «Христианском Чтении», в которой, в частности, показывает и доказывает возможность расчёта седмин пророка Даниила по олимпиадам. Александр Александрович утверждает, что «в год страданий Господа закончилась 201 - я олимпиада. Седмины пророка Даниила начались, как мы, надеюсь, не неосновательно доказали (Правосл. Собеседн. март 1886), с 13-го года царствования Артаксеркса; потому что пророчество ясно говорит, что с двадцатого года его царствования, или со времени дарования им Неемии указа о возобновлении крепости иерусалимской до дня смерти Мессии имели пройти семь седмин 62 седмины, то есть 69, а не 70 седмин. Семидесятая же седмина должна была примыкать непосредственно к году дарования указа» [20, с. 404]. То есть, исходя из всего вышеизложенного А. А. Некрасовым, можно сделать вывод, что датировка семидесятой седмины непосредственным образом связана с указом Артаксеркса Неемии о восстановлении Иерусалима. Таким образом, в своей полемической статье Александр Александрович Некрасов ещё раз доказывает важность чёткого и грамотного понимания исторического контекста, для правильного понимания текстов Священного Писания, «усиливающимся» доказывать обратное [21, с. 393]. 
Александр Дмитриевич Беляев (23. 07. 1849 - 29. 10. 1919) - профессор Московской Духовной Академии, доктор богословия, писатель, автор многочисленных трудов по догматике. В своём научном труде, опубликованном в 1894 году, он акцентирует внимание на пророчествах о «седьминах» Данииловых и о «мерзости запустения» и на толкование этих пророчеств отцами Церкви. А. Д. Беляев говорит о том, что пророчество святого Даниила повествует не только о судьбе еврейского народа, но также и о событиях земной жизни Иисуса Христа и, что возможно также и о последних временах мира: «Важность пророчества равняется таинственности его и трудности его изъяснения. Довольно сказать, что в нём - по мнению всех толкователей - предуказаны важнейшие события истории народа Божия за последний период её, по мнению большинства, оно, кроме того, есть пророчество мессианское, и в нём предсказаны как события конца ветхозаветной истории Еврейского народа, так и несравненно важнейшие события земной жизни Искупителя и начального времени истории христианской Церкви, наконец, по мнению некоторых, оно заключает ещё в себе предсказания о последних судьбах мира» [22, с. 194]. Особое внимание Александр Дмитриевич Беляев уделяет рассмотрению феномена «мерзости запустения», поскольку исчисление наступления этого времени напрямую связано с исполнением пророчеств святого пророка Даниила о семидесяти седьминах (Дан. 9, 24 - 27). А. Д. Беляев акцентирует внимание на наличии некоторых разногласий среди «древних толкователей» о времени наступления событий, о которых сказано в пророчестве святого пророка Даниила: «для устранения... разногласия между ветхозаветным и новозаветным пророчеством относительно одного и того же предмета, - времени явления мерзости запустения, можно найти материал уже и у древних толкователей. Однако и у них мы не находим согласия в определении как начала седьмин, так и конца их; равным образом и мнения их о мерзости запустения, о которой говорится в пророчестве о седьминах различны. ... но почти всеми, признаётся последней, семидесятой седьминой» [23, с. 199]. Такое точное исчисление седьмин и знание их времени и количества необходимо для расчёта времени прихода антихриста и «мерзости запустения». Решение этого вопроса Александр Дмитриевич Беляев, опираясь на святоотеческую традицию, видит в указании на последнюю «семидесятую» седьмину, поскольку «некоторые отцы, учители и писатели Церкви относили середину 
этой седьмины к моменту смерти Иисуса Христа, первую половину её - ко времени общественного служения Его, а вторую - к первым годам распространения христианства Апостолами после сошествия на них Св. Духа» [24, с. 199]. По нашему мнению, его выводы верны, поскольку основываются на самом тексте пророчества святого Даниила: «И утвердит завет для многих одна седмина, а в половине седмины прекратится жертва и принотение, и на крыле святилища будет мерзость запустения, $и$ окончательная предопределенная гибель постигнет опустошителя» (Дан. 9, 27).

Иван Степанович Якимов (1847 - 1885) - богослов, библеист, гебраист, профессор Санкт - Петербургской Духовной Академии. В 1884 году Иван Степанович издаёт свой научный труд, который посвящён исследовательским изысканиям о происхождении Книги пророка Даниила [25].

Василий Никифорович Потапов (1 (13) января 1837 - 5 (17) февраля 1890) - заслуженный экстраординарный профессор и почётный член Московской Духовной Академии, статский советник. В 1871 году он опубликовал в книге «Прибавления к Творениям святых Отцов за 1871 год часть XXIV» своё капитальное исследование «О книге святого пророка Даниила». Этот научный труд является его магистерской диссертацией, напечатанной в отдельном оттиске ещё в 1868 году. Это историко критическое исследование, «имеющее целью защитить православное воззрение на книгу пророка Даниила от превратных о ней мнений рационалистически мысливших богословов Запада» [26]. Василий Никифорович подробнейшим образом пересказывает содержание книги пророка Даниила, сопровождая это изложение своими пояснениями и комментариями. Анализируя сведения о подлинности Книги пророка Даниила В. Н. Потапов также утверждает, что «достоверность исторических сведений, сообщаемых во второй части книги пророка Даниила, имеющей преимущественно пророческое содержание, подвергалось так же, как и достоверность первой части некоторым нареканиям; тем не менее должна быть несомненна» [27, с. 118]. С этим сформулированным Василием Никифоровичем Потаповым выводом нельзя не согласиться.

Александр Петрович Введенский, протоиерей (08. 10. 1884 - 04. 04. 1973 ) - выпускник Московской Духовной Академии, магистр богословия, пастырь, проповедник, просветитель, духовный писатель, законоучитель Одесской 2 - й мужской гимназии. В 1912 году в Трудах Киевской духовной 
академии протоиерей Александр Петрович Введенский опубликовал научное исследование о «языке» Книги пророка Даниила в связи с историей её происхождения, в котором делает вывод о том, что «происхождение книги, не смотря на её двуязычие, относится к одному и тому же автору, а, следовательно, к одному и тому же времени, это видно из той тесной внутренней связи, какая замечается между первой и второй её частью, то есть между еврейской и арамейской. Эта связь до такой степени очевидна и так сильна, что отделить одну половину от другой совершенно невозможно». [28, c. 495]. Таким образом, по нашему мнению, А. П. Введенский вполне обоснованно делает вывод об авторстве и времени написания Книги пророка Даниила, указывая на период вавилонского пленения и личность самого святого пророка Даниила.

Александр Павлович Лопухин (10. 10. 1852 - 22. 08. 1904) - профессор Санкт - Петербургской Духовной Академии, богослов, библеист, переводчик, церковный писатель, исследователь и толкователь Священного Писания. Под его редакцией начал выходить фундаментальный многотомный труд: Толковая Библия, или Комментарии на все книги Священного Писания Ветхого и Нового Завета. Первое, состоящее из двенадцати томов, издание Толковой Библии вышло в Санкт - Петербурге, с 1904 по 1913 год, в виде бесплатного приложения к журналу «Странник». Один из томов этой грандиозной научной работы полностью посвящён пророческим книгам, и, в частности, Книге пророка Даниила. Её древность и каноническое достоинство утверждается на основании подробного анализа ветхозаветного канона и относящихся к нему текстов: «наличность книги пророка Даниила в древнейших исчислениях канонических книг является убедительным и ясным доказательством её канонического достоинства» [29, с. 16]. К несчастью, Александр Павлович умер в августе 1904 года. Дело его жизни продолжили его ученики, коллеги и преемники, такие как, например, профессора Александр Александрович Глаголев, Фёдор Герасимович Елеонский, Иван Гаврилович Троицкий и другие.

Михаил Иванович Херасков, протоиерей (1836 - 22. 09. 1901) - магистр богословия, библеист, педагог, писатель, ректор Владимирской Духовной Семинарии, основатель Епархиального женского училища, член цензурного комитета при Владимирской духовной консистории, рецензент во «Владимирских епархиальных ведомостях», член педагогических собраний 
Правления семинарии. Рецензент материалов на соискание премии митрополита Макария. Как исследователь историк и библеист. Протоиерей Михаил Херасков много потрудился на ниве духовного образования и просвещения. В частности, он составил и опубликовал книги - «Обозрение исторических книг Ветхого Завета» [30], а также «Руководство к последовательному чтению Пятикнижия Моисеева» [31], с приложением к ним Программ для преподавания Священного Писания в Духовных Семинариях. Наибольший же интерес, в связи с исследованием Книги святого пророка Даниила и её эсхатологических пророчеств, представляет его научный труд - «Послания апостольские и апокалипсис», в котором он исследует пророчества, относящиеся непосредственно к современности, и к кончине времён. М. И. Херасков особо отмечает, что «время пришествия Христова было прежде определено пророком Даниилом, оно кончилось в царство кесаря Августа, когда совершилось и воплощение Бога Слова, и явился Христос» [32, с. 260]. Эсхатологический аспект библейских книг, также остаётся в центре внимания протоиерея Михаила Хераскова, поскольку, по его мнению, «безопаснее и натуральнее всего, по примеру древних толкователей и отцов церкви, направлять содержание Апокалипсиса к последним судьбам мира, куда оно наибольшей частью своей, несомненно, и относится» [33, с. 473]. Тем самым протоиерей Михаил Херасков в исследовании текстов Священного Писания призывает придерживаться традиции святоотеческой экзегетики и герменевтики.

Д. Грацианский (сведений / данных об имени, дате рождения и смерти не найдено) - в июне 1914 года на пастырско-миссионерских курсах в городе Полтаве прочёл лекции в связи с обличением заблуждений секты адвентистов седьмого дня, и в сопоставительной форме изложил толкование книги пророка Даниила, а также эсхатологическую беседу Иисуса Христа о последних судьбах мира (Мф. 24, 1 - 42; Мк. 13, 4 - 37; Лк. 21, 7 - 36) и Апокалипсис святого Иоанна Богослова. На основе этих лекций в 1915 году в Полтаве он издал книгу: «Рассмотрение книги пророка Даниила эсхатологической беседы Господа Иисуса Христа и книги Откровения св. Иоанна Богослова». Д. Грацианский использует святоотеческую экзегетику при анализе текстов Священного Писания. Также, полемизируя с трактовкой данных текстов Священного Писания адвентистами седьмого дня, Д. Грацианский утверждает, что «отличительные, чисто сектантские 


\section{ИННОВАЦИОННОЕ РАЗВИТИЕ НАУКИ: ФУНДАМЕНТАЛЬНЫЕ И ПРИКЛАДНЫЕ ПРОБЛЕМЫ}

особенности в понимании евангельской эсхатологии, коими характеризуется секта адвентистов, яснее будут поняты, когда мы изложим толкование адвентистами книги пророка Даниила, 24 главы Евангелия от Матфея (и паралл. мест) и Откровения» [34, с. 8]. Таким образом, указывая на «натяжки», манипуляции, непонимание или искажения в трактовке текстов Библии адвентистами Д. Грацианский наглядно демонстрирует их отступления от Истины. Однако, субъективизм последних, вполне объясним, поскольку «духовное бытие связано с освобождением человека от своей самости, являющейся границей между душевным и духовным бытием» $[35, \mathrm{c}$. 5]. Данный факт в очередной раз напоминает нам о том, что изучение Священного Писания требует от исследователя строгого отношения не только к изучаемому тексту, но и к самому себе, потому что «без духовно нравственного преображения, совершенствования и бытия человека невозможно правильное понимание и толкование Священного Писания, поскольку основное видение очами духовными доступно только христианам» [36, с. 145]. Таким образом, текст данной научной работы Д. Грацианского одновременно сочетает в себе полемику обличения лжеучения и апологетику христианского вероучения. Ознакомление с данным трудом Д. Грацианского важно не только в историческом контексте богословской полемики, но как практический опыт актуально для современного православного богословия.

Итак, мы рассмотрели и проанализировали наиболее важные, по нашему мнению, труды профессоров и преподавателей Духовных школ XIX и XX веков, посвящённых исследованию Книги пророка Даниила. Исходя из всего вышеизложенного, по нашему мнению, следует отметить, что проблема исследования Книги пророка Даниила на протяжении веков и столетий не перестаёт быть актуальной для многих поколений исследователей, поскольку «Священное Писание Ветхого и Нового Заветов многократно утверждает факт исключительности пророческого служения и характеризует его не только как дар от Бога, но и как подвиг человека» [37, с. 89]. В связи с этим, подвиг исследователя текстов Священного Писания заключается в правильном и обоснованном разъяснении библейских смыслов. Таким образом, на основании проведённого нами научного исследования, обозреваемых в данной научно - исследовательской работе, научных трудов учёных Духовных школ, можно смело утверждать, что практически все эти научные труды не утратили своей актуальности, и являются серьёзным научным 
основанием для дальнейших исследований в различных областях, в том числе, в области православного богословия.

\section{Список литературы}

1. Библия. - Москва: Российское Библейское Общество, 2020. - 1337 с.

2. Плохий Е. В. Личность пророка Даниила в контексте библейской истории. // Научный потенциал молодёжных исследований: сборник статей III Международной научно-практической конференции (3 мая 2021 года). Петрозаводск: МЦНП «Новая наука», 2021. - С. 242 - 248.

3. Праведный Александр Юнгеров, Чагринский, протоиерей. [Электронный ресурс] - URL: https://azbyka.ru/days/sv-aleksandr-jungerov-chagrinskij (дата обращения: 03. 05. 2021).

4. Святой Ипполит, епископ Римский. О Христе и антихристе. - СПб. : Изд - во «Библиополис», 2008. - 400 с.

5. О седмидесяти толковниках и о тех, которые ложно истолковали Священное Писание. // Творения святого Епифания Кипрского: В шести частях. Часть. 6. - Москва, [1883]. - С. 283 - 290.

6. Профессор Павел Александрович Юнгеров. Введение в Ветхий Завет. [Электронный ресурс] - URL: https://azbyka.ru/otechnik/Pavel_Yungerov/ vvedenie-v-vethij-zavet/4_2 (дата обращения: 03. 05. 2021).

7. Профессор Павел Александрович Юнгеров. [Электронный ресурс] URL: https://azbyka.ru/otechnik/Pavel_Yungerov/ (дата обращения: 03. 05. 2021).

8. Святый пророк Даниил, его время, жизнь и деятельность / [сочинение] С. А. Песоцкаго. - Киев: Типография Корчак - Новицкаго, 1897. $\mathrm{I}-\mathrm{V} ;-491 \mathrm{c}$.

9. Указанное сочинение С. А. Песоцкаго.

10. Григорьев И. Ф. Русский синодальный перевод Книги пророка Даниила: (Критический этюд): Речь, предназначенная для произнесения в Торжественном годичном собрании Казанской духовной академии 8 - го ноября 1918 г., проф. И. Григорьева. - Казань: [б. и.], 1918. - 23 с.

11. Святой пророк Даниил и его книга. / Составил преподаватель Витебской Духовной семинарии Алексей Разумовский. - С. - Петербург: Издание Книгопродавца И. Л. Тузова. Гостиный двор, № 45, 1891. - 163 с. 
12. Иоанн (Смирнов, Иван Ксенофонтович). Св. пророк Даниил / Сочинение Инспектора Рязанской духовной семинарии Ивана Смирнова. Рязань: Губернская типография, 1879. - [2] - 387 с.

13. Св. пророк Даниил. Очерк его века, пророческого служения и священной книги. / Сочинение А. Бухарева - Москва: Издание Книгопродавца А. И. Манухина, 1864. - 190 с.

14. Указанное сочинение А. Бухарева.

15. Указанное сочинение А. Бухарева.

16. Указанное сочинение А. Бухарева.

17. Указанное сочинение А. Бухарева.

18. Указанное сочинение А. Бухарева.

19. О подлинности и целости священных книг пророков: Исаии, Иеремии, Иезекииля и Даниила. / Сочинение А. Бухарева. - Москва: Издание Книгопродавца А. И. Манухина, В Типографии Бахметева, 1864. - 174 с., II c.

20. Седмины пророка Даниила по олимпиадам. (По поводу статьи Степана Дорошкевича: «Хронология книг 1-й Ездры и Неемии», помещённой в Христианском чтении за июль - август 1886 года»). / Сочинение А. Некрасова. // Православный собеседник, Издание Казанской Духовной Академии. Часть первая. Апрель. - Казань: Типография Императорского Университета, 1887. - С. 393 - 407.

21. Указанное сочинение А. Некрасова.

22. Седьмины Данииловы. / Александр Беляев. // Богословский вестник, издаваемый Московскою Духовною Академиею. - Т. 1. - № 2. (2-я пагин.). (Начало.). - Январь 1894. - 2 - я Типография А. И. Снегиревой в Сергиевом Посаде Московск. о. - С. 193 - 228.

23. Указанное сочинение Александра Беляева.

24. Указанное сочинение Александра Беляева.

25. Якимов И. С. Происхождение книги пророка Даниила / [Экстраорд. проф. Ив. Якимов]. - [Санкт-Петербург, 1884]. - 67 с.

26. Корсунский И. Н. Профессор В. Н. Потапов: Некролог. [Электронный ресурс] - URL: https://azbyka.ru/otechnik/Ivan_Korsunskij/ professor-v-n-potapov/ (дата обращения: 03. 05. 2021).

27. Потапов В. Н. О книге святого пророка Даниила. // «Прибавление к изданию творений Святых Отцев в русском переводе». 1871. XXIV. C. $1-146$. 
28. Введенский Александр, прот. Язык книги пророка Даниила в связи с историей её происхождения: по поводу новонайденных ассуанских и элефантинских папирусов. // Труды Киевской Духовной Академии. - IV. Киев, 1912. - С. 493 - 510.

29. Толковая Библия, или Комментарии на все книги Св. Писания Ветхого и Нового Завета под редакцией А. П. Лопухина: В 7 - ми томах. Том V: Пророческие книги. Изд. 4 - е. - Москва: Изд - во «ДАРЪ», 2009. - 992 с.

30. Обозрение исторических книг Ветхого Завета, составленное протоиереем Михаилом Херасковым и одобренное Святейшим Синодом для употребления в Духовных Семинариях в качестве учебного руководства. Издание пятое. - Владимир на Клязьме: Типография Н. А. Паркова, 1908. 432 с. - Прогр. для преподавания Священного Писания в Духовных Семинариях, изданная учеб. комитетом при Святейшем Синоде. Класс II. С. I - XIII.

31. Руководство к последовательному чтению Пятокнижия Моисеева составленное протоиереем Михаилом Херасковым и одобренное Святейшим Синодом для употребления в Духовных Семинариях в качестве учебного руководства. Издание пятое. - Губернский город Владимир: Типо Литография Н. А. Паркова, 1896. - 288 с. - Программа для преподавания Священного Писания в Духовных Семинариях. Класс I. - I - VIII.

32. Послания апостольские и апокалипсис. Истолковательное обозрение, составленное протоиереем Михаилом Херасковым, применительно к программе преподавания священного писания в духовных семинариях и удостоенное 500-ной премии преосвященного митрополита Макария. Издание третье. - Владимир на Клязьме: Типография Н. А. Паркова, 1907. - 516 с. Оглавление книги I - LII.

33. Послания апостольские и апокалипсис. Истолковательное обозрение, составленное протоиереем Михаилом Херасковым, применительно к программе преподавания священного писания в духовных семинариях и удостоенное 500-ной премии преосвященного митрополита Макария. Издание третье. - Владимир на Клязьме: Типография Н. А. Паркова, 1907. - 516 с. Оглавление книги I - LII.

34. Грацианский Д. Рассмотрение книги пророка Даниила эсхатологической беседы Господа Иисуса Христа и книги Откровения св. Иоанна Богослова в связи с обличением заблуждений секты адвентистов 7-го дня. - Полтава: Электрическая типография Г. И. Маркевича, 1915. - 112 с. 
35. Байдакова М. Ю. Проблема воли в философии и христианской антропологии: автореферат диссертации кандидата философских наук: 09.00.01. - Москва, 2008. - 26 с.

36. Неганов В.В. Основные тенденции развития философских и богословских взглядов на допустимые методы толкования Священного Писания в экзегетике каппадокийских Отцов Церкви (святитель Василий Великий). // Вестник Московского государственного областного университета. Серия: Философские науки. - Москва: Изд - во МГОУ, 2018. - № 3. C. $139-149$.

37. Плохий Е. В. Пророческое служение святого Даниила как пример особой миссии пред Богом и людьми. // Консолидация интеллектуальных ресурсов как фундамент развития современной науки: сборник статей IV Международной научно-практической конференции (6 мая 2021 года). Петрозаводск: МЦНП «Новая наука», 2021. - С. 88 - 93.

(C) Е.В. Плохий, 2021 